\title{
The Restructuring of the Institutional Real Estate Portfolio in the UK
}

\section{Colin Jones $^{1}$, Neil Dunse ${ }^{1}$, Nicola Livingstone ${ }^{2}$ and Kevin Cutsforth ${ }^{3}$}

\begin{abstract}
Real estate investment portfolios of financial institutions have seen dramatic changes over the last three decades or more. Historically such property investment decisions have been seen within a portfolio diversification paradigm that has sought to balance risk and return. This paper considers the role of the supply of assets in the determining and constraining the UK institutional portfolio. The supply of real estate assets not only expands during property booms but has also been transformed by a long term urban development cycle as cities adapt to cars and the ICT revolution that has brought new property forms. The research examines long term trends in investment change by disaggregating into ten property forms rather than the usual three land use sectors. It then assesses to what extent investment patterns can be explained in terms of portfolio theory, short term net returns of individual sectors or driven by the supply of real estate assets. It concludes that the supply of real assets is an overlooked explanation.
\end{abstract}

1 Urban Institute, Heriot-Watt University, Edinburgh

2 Bartlett Planning School, University College London

3 School of Civil Engineering and Surveying, University of Portsmouth 


\section{Introduction}

The real estate investment portfolios of financial institutions have seen dramatic changes over the last three decades or more. Historically such property investment decisions have been seen within a portfolio diversification paradigm that has sought to balance risk and return. However, increasingly other explanations have been considered in terms of behavioural influences. These include benchmarking or the importance of relative liquidity of different types of real estate assets. None of these approaches have addressed the reality of investment decisions that are taken in the context of a dynamic commercial property market. In particular, the supply of real estate assets not only expands during development booms but has also been transformed as the spatial structure of cities and property forms adapt to the motor age and the ICT revolution. These dynamics are ubiquitous and represent important challenges for investors around the world. This is an overlooked perspective on property investment decisions and the backdrop to the paper.

It is the first to assess the role of the (changing) supply of assets on commercial property investment decisions. It addresses this task through a focus on the determinants and constraints on the UK 'institutional investment commercial property portfolio'. The UK is chosen for the study because of the data availability. The paper has two objectives. First, the research examines the patterns of investment portfolio change. Second, it will then assess to what extent investment patterns can be explained in terms of portfolio theory, short term net returns of individual sectors or driven by the supply of real estate assets.

The paper begins by reviewing the research on approaches to constructing a real estate portfolio. It then charts the nature of changes in the investible property universe in the UK over the thirty years 1981 to 2010 based on data from the MSCI/IPD Digest. The next section considers annual net transaction flows into different types of property from 1981 to 2010 distinguishing between trends and cycles. The latter part of the paper undertakes an empirical analysis of the underlying explanations for these changes. First, it examines the links between investment patterns and investment returns. This is followed by a section assessing whether net investment flows can be seen as part of an optimising process based on the changing risk and return characteristics of the total real estate portfolio over this period. Finally the role of physical changes to the supply of real assets is then reviewed. In the conclusion we assess the competing explanations 


\section{Constructing a Real Estate Portfolio}

At the heart of investment portfolio building is the balance between risk and return. One of the most fundamental questions for investors beneath this overarching balance is how to optimally diversify their portfolios to reduce non-systematic risk. Direct investment in real estate is one potential component of a diversified portfolio as it has a distinctive pattern of returns over time. Indirect investment in property through shares in real estate investment trusts (REITs) follow the stock market rather than the property market in the short term (Kroenke et al, 2014). While international research finds that REITs follow property returns on a long term horizon the key short term diversification benefits of direct investment are lost (Hoesli and Oikarinen, 2012). Given that REITs have these short term investment characteristic the focus in this paper is only on direct real estate portfolios.

The diversification issue actually has a number of tiers to it. First, there has been much discussion about the appropriate investment balance between shares, bonds and direct real estate. This has spawned a literature about the role of real estate in a multi-asset portfolio, and the optimal percentage of real estate that a portfolio should include. Using different methodologies a wide range of studies including Hamelink and Hoesli (1996) and MacGregor and Nanthakumaran (1992) have derived a strong positive impact of including real estate in mixed-asset portfolios, a finding that Liang and McIntosh (1998), among others, have confirmed for the US market. Studies typically propose that the real estate allocation in a mixed-asset portfolio should be the order of 15-20\% (Hoesli and MacGregor, 2000).

A related set of studies using the same basic framework have considered how to construct the most diversified real estate portfolio. The focus of this research has been on the diversification choice between real estate sector (use type) and spatial location/region. It is not possible to review this wide literature here, see Byrne and Lee (2011) for a thorough summary. These studies have used different basic areal units and techniques but all divide the real estate market into three sectors - industrial, offices and retail. There are many issues that arise from the areal units applied in these studies across a number of continents but the general conclusion is that the principal route to diversification is based on sectors rather than areas at least in the first instance. This has become a widely held belief albeit based on using only a three sectoral classification (and ignoring issues about the area definitions applied, but see below). These analyses are essentially based on the variation in return cycles of the different types of assets. 
The latest paper in this tradition is Jackson (2013) who compares the results of different local areal groupings on optimal risk diversification. The findings show that the choice of groupings does make a difference. Using efficient frontiers it also demonstrates the gulf between optimally determined real estate asset allocations, in terms of use sector and location, and observed institutional weightings. Potential explanations lie in the simple assumptions of portfolio theory that do not hold for real estate markets. The concept of the optimal share of real estate assets in a mixed asset portfolio or real estate portfolio composition largely stems from the Markowitz (1952) approach that examines returns while risk is calculated by examining the standard deviations and covariance of the assets. It has been criticised because the pure mean-variance approach to portfolio construction is not necessarily relevant to many institutional investors that increasingly view risk as a downside phenomenon or investment within a liability-driven investment (LDI) strategy. As a result, risk is not volatility per se but the chance of a negative surprise that inhibits the hoped for objectives. In this case, investor preferences are more weighted to the downside and the possibility of loss or returns falling below some threshold return (Kaiser and Clayton, 2008).

In this regard Byrne and Lee (2004) consider portfolio asset allocation models using other measures of risk, namely semi-variance (down-side risk only), lower partial moments, the MM rule that seeks to minimise the maximum loss (negative gain), and the mean absolute deviation (MAD). The authors find that the portfolio compositions produced by different risk measures vary markedly with the risk measure applied. These authors subsequently apply the MAD approach to optimise portfolios to revisit the sector versus regional diversification debate within the UK over the period 1981-2007 (Byrne and Lee, 2011).

A further problem with the Markowitz world is not just the measurement of risk but also that there is no difference between the short and long term because of the assumptions. This is especially important for real estate because transaction costs and lack of liquidity are evident market frictions that limit the scope for applying the model to such an investment. Rehring (2012) also argues that the traditional mean-variance approach of the Markowitz model ignores the role of investment horizons and in particular the predictability of returns, and can therefore be misleading. He notes that Campbell and Viceira (2005) show that return predictability in particular generates major investment vista effects in assessing risk and return so that the optimal asset allocation depends on the investment horizon. 
The precise horizon is open to debate. Rehring (2012) argues that given the nature of the property market, risk and return are best measured over 'long' time horizons. Kaiser and Clayton (2008) refer to Geltner (2000) who argues that three years may not be sufficient and Sivitanides (1996) who found four-year returns more statistically reliable than annual returns. They note that a rolling five year horizon can be seen as the shortest time period for risk and return measurement. Whatever the precise horizon in the investment decision making process expected future returns are based on uncertain forecasts and sentiment that is partly based on (recent) historic economic and real estate trends and cycles.

Jackson (2013) also suggests that historic investment patterns and the need for liquidity are key further influences on portfolio construction, as well as herding linked to benchmarking, that could challenge the logical functioning of financial decisions based on risk and return (Baum, 2015; Henneberry and Roberts, 2008). The importance of liquidity is seen in the perception of London as the most liquid office market that according to Lizieri (2009) explains its dominance in institutional portfolios, even if it is the most volatile and inefficient compared to other UK cities (Dunse et al, 2010).

The historic development of institutional portfolios is an important factor that mitigates against optimal portfolios. Looking back institutional property portfolios arose originally partly through sale and lease backs. Scott (1996) notes their existence in the 1890s and how they had been used by individual retailers to expand their business, particularly from the 1930s on. A retailer could enter into a sale and lease back arrangement on one store, and use the finance to buy another, and by this process establish a chain of shops. Much later supermarkets became a noticeable part of the institutional portfolio when these chains decided they wanted to carry out sale-andleasebacks to fund store expansion programmes. This is an example of how the supply of potential property assets increased.

Models of investment implicitly presume an infinite supply/choice of assets to select from. In practice this is not possible as the stock is fixed in the short term and at any one time the flows of available property for sale are limited. The picture is further complicated by the characteristics of the real estate supply universe changing over time, as in the case of the supermarkets above. More generally property investment is underpinned by occupation demand which is not static, with changes to required building and location specifications driving development and redevelopment. 
Recent examples include moves toward green buildings and larger shop sizes. Demand is also cyclical.

This necessity to adapt to change is partly implicitly recognised by active portfolio management that involves the selection of individual properties with specific risk. Kaiser (2005) distinguishes between three types of risk. Alpha relates to the return from focusing on particular property types or geographies or properties. Beta relates simply to market risk following the capital asset pricing model and Gamma, the change in value due to actions under the manager's control. This latter risk emanates from attempts to add value by controlling the asset and working to improve its cash flow for example through refurbishment or re-development.

This final aspect of risk identified by Kaiser is implicitly based on the important role of supply on real estate investment. The stock of real estate investments is dynamic and the nature of the investment opportunities change over time. But this is not simply the consequence of decisions by investors trying to improve cash flow per se. Real estate investment must be seen in the context of its occupation demand set primarily within changing urban economies but also information and transport technologies, and cycles in the short term. There have in particular been fundamental changes in urban real estate markets in the form of decentralisation and new property forms such as office parks and retail warehouses as discussed in the next section (Jones, 2009). In fact it can be argued that there has been a significant urban development cycle since 1980 that has led to substantial upheaval in cities with important implications for real estate investment not only in terms of property forms and location but also for tenant turnover and liquidity (Jones et al, 2016). The paper now considers this impact of this urban development cycle on institutional real estate investment.

\section{Restructuring of UK 'Institutional Portfolio’ 1981-2010}

The 'institutional portfolio' can be defined by the MSCI/IPD universe. The MSCI/IPD database is constructed from the portfolios of its contributors, primarily financial institutions. It has traditionally been weighted toward properties owned by insurance companies and pension funds but also includes the portfolios of some of the larger publicly quoted property companies/REITS and real estate investment funds. It approaches almost complete coverage for some major categories of institutional property owner, and although the composition of funds has changed over time the data has always been an essential representation of the domestic institutional investment market (Mitchell, 2014). Nevertheless the database does not include all institutional 
investors or overseas investors such as sovereign wealth funds. The time series analysis stops in 2010 as there is a potential bias caused by the subsequent significant expansion in investment from overseas. It should be remembered that overall the UK investment stock is more heavily weighted toward City of London offices, and retail warehouses are also 'over-represented' in the database in terms of the numbers in the investment database (see below).

The restructuring of the institutional portfolio is analysed here by reference to the change in investment in property 'segments' over five year intervals between 1981 and 2010. The data is drawn from the MSCI/IPD Digest, that as of 2010 contained 11,276 properties across 283 investment funds with a total capital value of $£_{135.4 b n}$ (MSCI/IPD, 2010). Unlike the previous portfolio studies the research differentiates real estate investments into ten segments rather than the traditional three land use sectors. The segments are a classification developed by MSCI/IPD that encompass a range of property types and are listed in Table 1. Disaggregation into these segments highlights the dynamic nature of property investment. The analysis below demonstrates the emergence of some of them and the decline of others that represents an important reformulation of that the real estate offering and supply (accepting the bias of the database).

Table 1 Changing Institutional Portfolio in the UK

\begin{tabular}{|l|c|c|c|c|c|c|c|}
\hline $\begin{array}{l}\text { Property } \\
\text { Segment }\end{array}$ & $\begin{array}{c}\mathbf{1 9 8 1} \\
\mathbf{0}\end{array}$ & $\begin{array}{c}\mathbf{1 9 8 5} \\
\mathbf{0}\end{array}$ & $\begin{array}{c}\mathbf{1 9 9 0} \\
\mathbf{0}\end{array}$ & $\begin{array}{c}\mathbf{1 9 9 5} \\
\mathbf{\%}\end{array}$ & $\begin{array}{c}\mathbf{2 0 0 0} \\
\mathbf{\%}\end{array}$ & $\begin{array}{c}\mathbf{2 0 0 5} \\
\mathbf{0}\end{array}$ & $\begin{array}{c}\mathbf{2 0 1 0} \\
\mathbf{\%}\end{array}$ \\
\hline Standard Shop & 15.2 & 18.7 & 16.8 & 16.8 & 13.8 & 10.9 & 10.3 \\
\hline $\begin{array}{l}\text { Shopping } \\
\text { Centre }\end{array}$ & 9.4 & 12.1 & 12.7 & 17.3 & 18.4 & 19.6 & 17.9 \\
\hline $\begin{array}{l}\text { Retail } \\
\text { Warehouse }\end{array}$ & 0.6 & 0.9 & 2.9 & 7.8 & 12.4 & 18.1 & 19.4 \\
\hline $\begin{array}{l}\text { Department/ } \\
\text { Variety Store }\end{array}$ & 1.9 & 1.8 & 1.9 & 2.2 & 1.8 & 1.5 & 1.3 \\
\hline Supermarket & 0.7 & 0.9 & 0.5 & 2.1 & 1.5 & 1.4 & 3.8 \\
\hline Other Retail & 0.3 & 0.4 & 0.5 & 0.7 & 0.7 & 0.6 & 0.8 \\
\hline $\begin{array}{l}\text { Standard } \\
\text { Office }\end{array}$ & 56.2 & 52.2 & 50.5 & 36.8 & 33.6 & 28.5 & 27.8 \\
\hline Office Park & 0.0 & 0.5 & 2.2 & 2.9 & 4.6 & 4.1 & 3.4 \\
\hline $\begin{array}{l}\text { Standard } \\
\text { Industrial }\end{array}$ & 15.0 & 11.9 & 11.1 & 11.1 & 10.4 & 12.3 & 11.9 \\
\hline $\begin{array}{l}\text { Distribution } \\
\text { Warehouse }\end{array}$ & 0.5 & 0.5 & 1.0 & 2.4 & 2.8 & 3.0 & 3.3 \\
\hline
\end{tabular}

\section{Source: MSCI/IPD (2010)}

Note: The variations in the distributions from one period to another are influenced by changes in yields. 
Direct property investment in the UK by financial institutions demonstrates a degree of fluidity over the thirty year study period. At the beginning of the 1980s standard offices dominate the institutional portfolio with more than half total investment. Over the 1980 s their popularity begins to wane and from 1994 retailing becomes the largest component of institutional portfolios. Meanwhile the minority position of industrial property lies unscathed by these substantial changes. However, beneath the surface of the redistribution between the aggregate sectors there is arguably a more fundamental transformation not considered in other portfolio studies.

Change is almost revolutionary in the retail sector with the emergence of out of town shopping. Retail warehouses appeared in the 1980s as a new retail format, and while comprising in 1981 less than $3 \%$ of the institutional portfolio by 2010 they represent almost a fifth of total investment. Overall investment in decentralised retail formats rose from only a nominal proportion to $46 \%$ of all retail investments in 2006, and by 2010 are on a par with town centre developments $50 \%$ if department stores are included) (Jones, 2010). In contrast the high street shop, the mainstay of retail investment in the 1980 s falls from $18.7 \%$ of the institutional portfolio in 1985 to $10.3 \%$ in 2010 as Table 1 shows.

In parallel office parks were established during the 1980s, and climb to around $10 \%$ of office investment in 2010. Distribution warehouses similarly have developed over the thirty years to a distinct investment class. These changes can be seen as the latest in a series of urban development cycles lasting approximately thirty years caused by technological progress and identified by Barras (1987). The impact of car travel and the rapidly developing ICT technology means that property forms have been developed to meet new demand requirements. The maturation and establishment of these new property forms into mainstream institutional investments is part of a substantial transformation of cities.

The result of these developments is that the institutional portfolio in 2010 is very different from that in 1981. Offices that represented more than half the portfolio at the beginning of the period by 2010 account for 31\%. Notwithstanding the huge structural changes in retail investment the sector as a whole accounted for over half of institutional investment by 2010 . There is therefore a fundamental relative shift from offices to retail with investment in industrial property including warehousing broadly stable in proportional terms. 
Over the three decades the property market experienced two major booms and busts. During the booms a vast increase in investment funds was attracted into the commercial property market, especially after the collapse of the dot-com bubble beginning in 2000 (Jones et al, 2017). To control for any potential impact that this may create the next section identifies long term statistical trends.

\section{Decomposition of Investment Segment Trends}

To better understand the changing dynamic of the institutional portfolio over time the annual net real change in investment in each separate segment is now reviewed. To quantify and isolate the trend components of this net investment activity the Hodrick Prescott (HP) filter is applied. The HP Filter is an established statistical procedure used to separate the cyclical component from the long term trend in a time series of raw data. The conceptual framework is that for a given time series, $y_{t}$ is the sum of a trend component $\tau_{t}$ and cyclical component, $c_{t}$. That is,

$y_{t}=\tau_{t}+c_{t}$

Hodrick and Prescott (1997) suggest a way to isolate $c_{t}$ from $y_{t}$ is by the following penalised minimisation equation (2), where $\lambda$ is the penalty parameter.

$\min \sum_{t=1}^{\mathrm{T}}\left(\left(\mathrm{y}_{\mathrm{t}}-\tau_{\mathrm{t}}\right)^{2}+\lambda\left(\left(\tau_{\mathrm{t}+1}-\tau_{\mathrm{t}}\right)-\left(\tau_{\mathrm{t}}-\tau_{\mathrm{t}-1}\right)\right)^{2}\right)$

The first term, sum of squared deviations, $y_{t}-\tau_{t}$, (the deviation from the trend) is commonly referred to as the cyclical component and minimising this term penalises the variance of the cyclical term, $c_{t}$ The second term is a multiple $\lambda$ of the sum of the squares of the trend component's second differences and penalises variations in the growth rate of the trend component, $\tau_{\mathrm{t}}$. The larger the value of $\lambda$, the higher is the penalty. As $\lambda$ approaches to zero, the trend component becomes equivalent to the original series and as $\lambda$ diverge to $\infty$, the trend component approaches to the linear trend.

As originally suggested by Hodrick and Prescott it is customary to set $\lambda$ to 1600 for quarterly data (Ravn and Uhlig, 2002). However, in this study we are using annual data and there has been some debate amongst the academic literature as to the value of $\lambda$ for annual data. Correia et al (1992) and Cooley and Ohanian (1991) use a value of 400, whereas Backus and Kehoe (1992) use a value of 100. There does appear to some evidence that the value should be considerably lower. Baxter 
and King (1999) apply a value of around 10, a result broadly supported by Maravall and del Rio (2007) who recommend to use $6<\lambda<14$. Ravn and Uhlig (2002) draw a similar result stating that $\lambda$ should vary by the fourth power of the frequency observation ratio $\left(1600 / 4^{4}\right)$; thus, $\lambda$ should equal 6.25 for annual data. In accordance with this conclusion we report results for a $\lambda$ of 6.25 although for comparison we also tested the higher values of 25, 100 and 400 . The higher the $\lambda$ the smoother the trend and the element of cyclicity is reduced. Higher values also bring the turning points in the trend forward so that for example peak values occur in the early noughties rather than just before the credit crunch. This finding supports the use of the low value for $\lambda$.

The trends identified from this statistical analysis are presented in Figures 1-3. Net real investment in standard offices has a declining trend through the 1980s before plateauing in the first half of the 1990s. There is a brief upward trend in investment in the latter half of that decade before a sharp downturn around the millennium. Another subsequent revival in real investment in offices is again short lived and following the global financial crisis (GFC) net investment becomes negative. This rapid decline is undoubtedly associated with an explosion of foreign investment in central London (Mitchell, 2014). Net real investment in office parks follows a different path with a modest upward trend through the 1980s and 1990s. The turn of the century represents the peak of their popularity and net investment then falls away becoming negative from 2006; a trend that seems unaffected by the GFC (Figure 1).

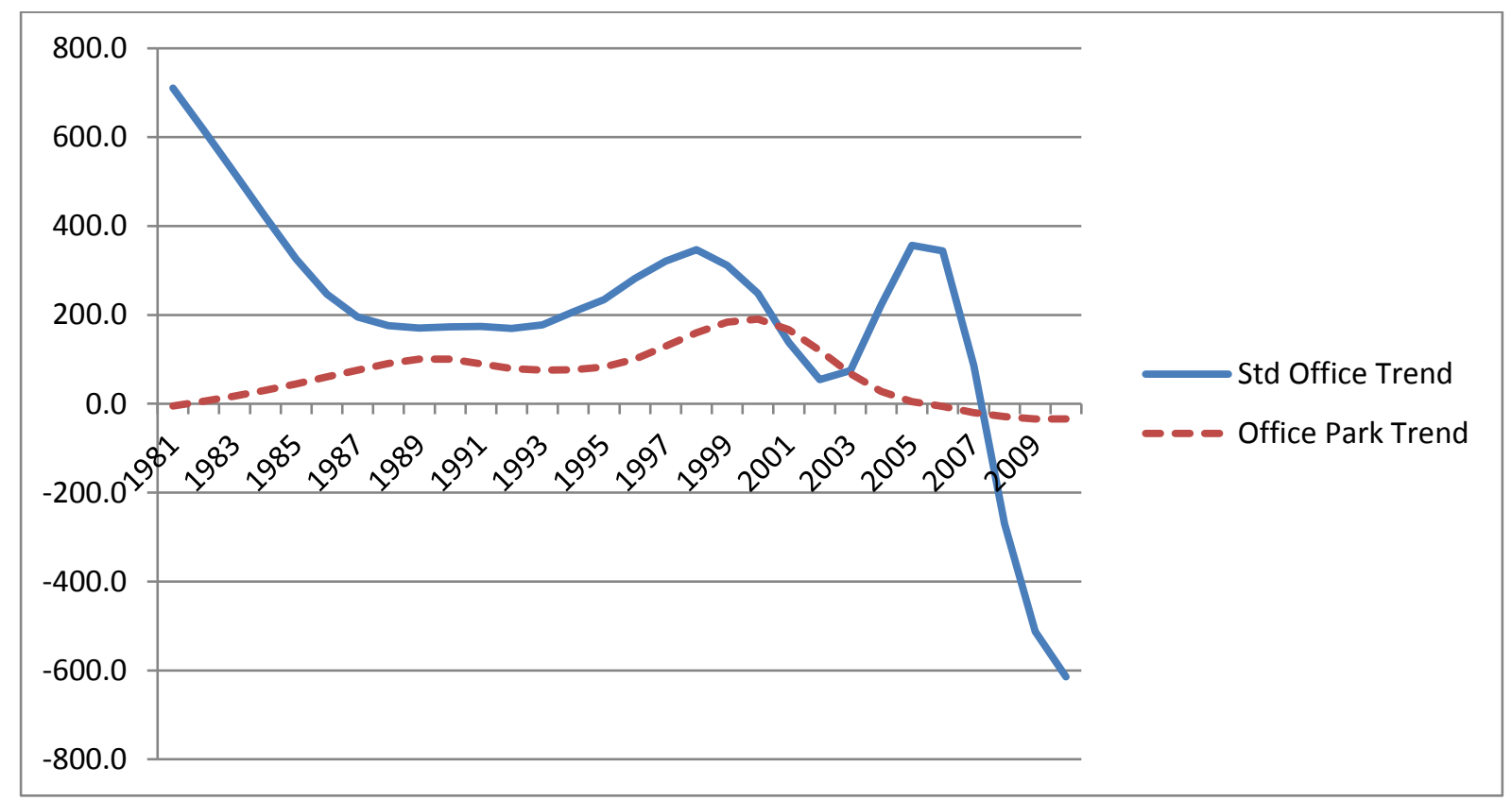

Figure 1 Trends in Net Real Investment in Offices and Office Parks 


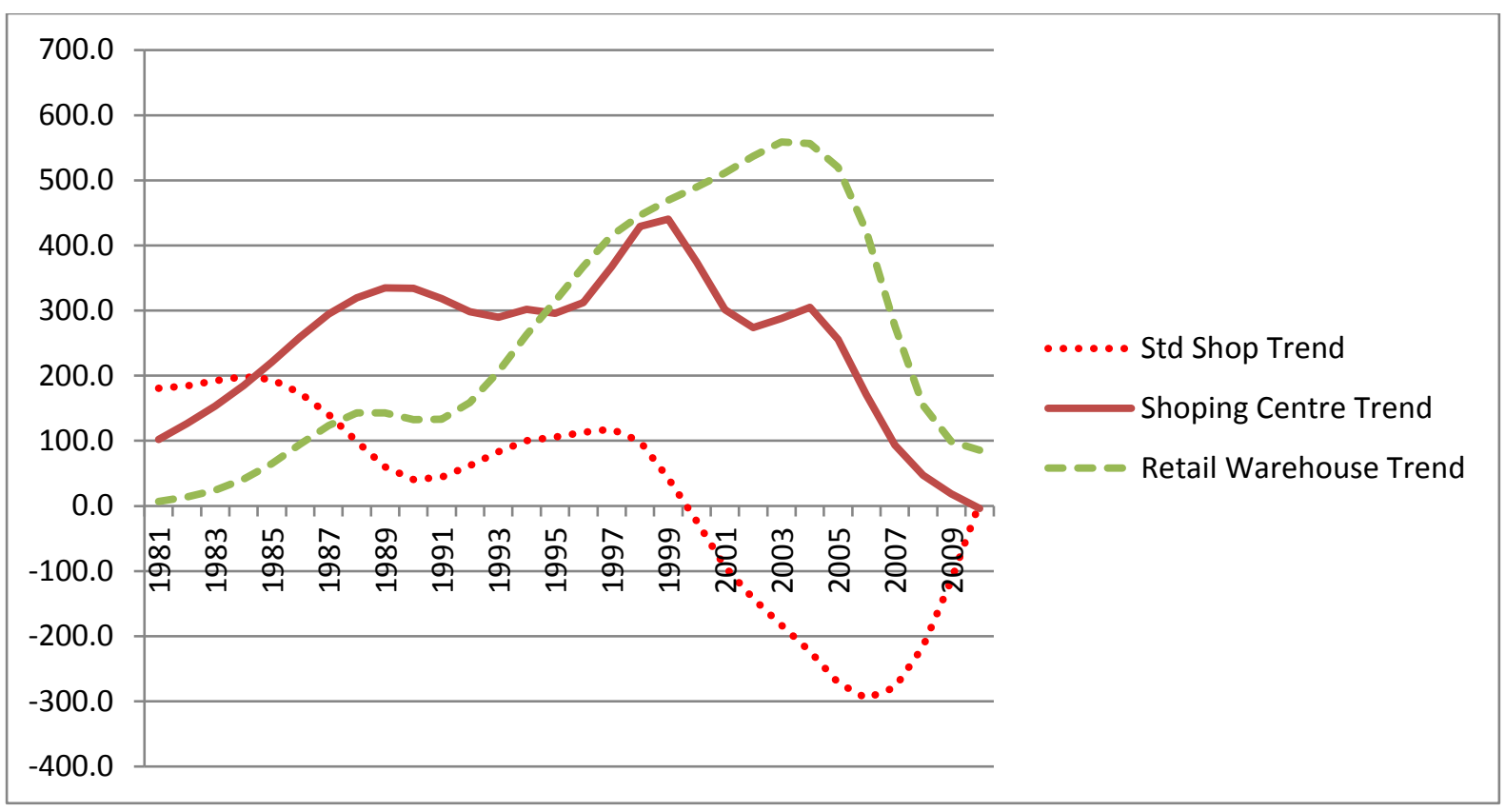

Figure 2 Trends in Net Real Investment in Shops, Shopping Centres and Retail Warehouses

The trends for standard shops sees net real investment fall by three quarters over the last half of the 1980s. While there is a modest recovery in the 1990s there then follows a major divestment of these assets from 1998 on. Figure 2 suggests that this process may now have been completed. The investment trend in retail warehouses is almost a mirror image with dramatic growth in the 1990s and the first half of the 2000s. Net real investment peaks just before the GFC. Investment purchases of shopping centres rise substantially first in the 1980s, reaching a peak in net real investment at the millennium. Net positive investment in shopping centres continues through the following decade at a declining rate. Supermarkets have a very distinctive investment pattern with modest interest from 1981 through to 2005 there is then a dramatic rise in popularity in the latter half of the 2000s (not shown in a figure). 


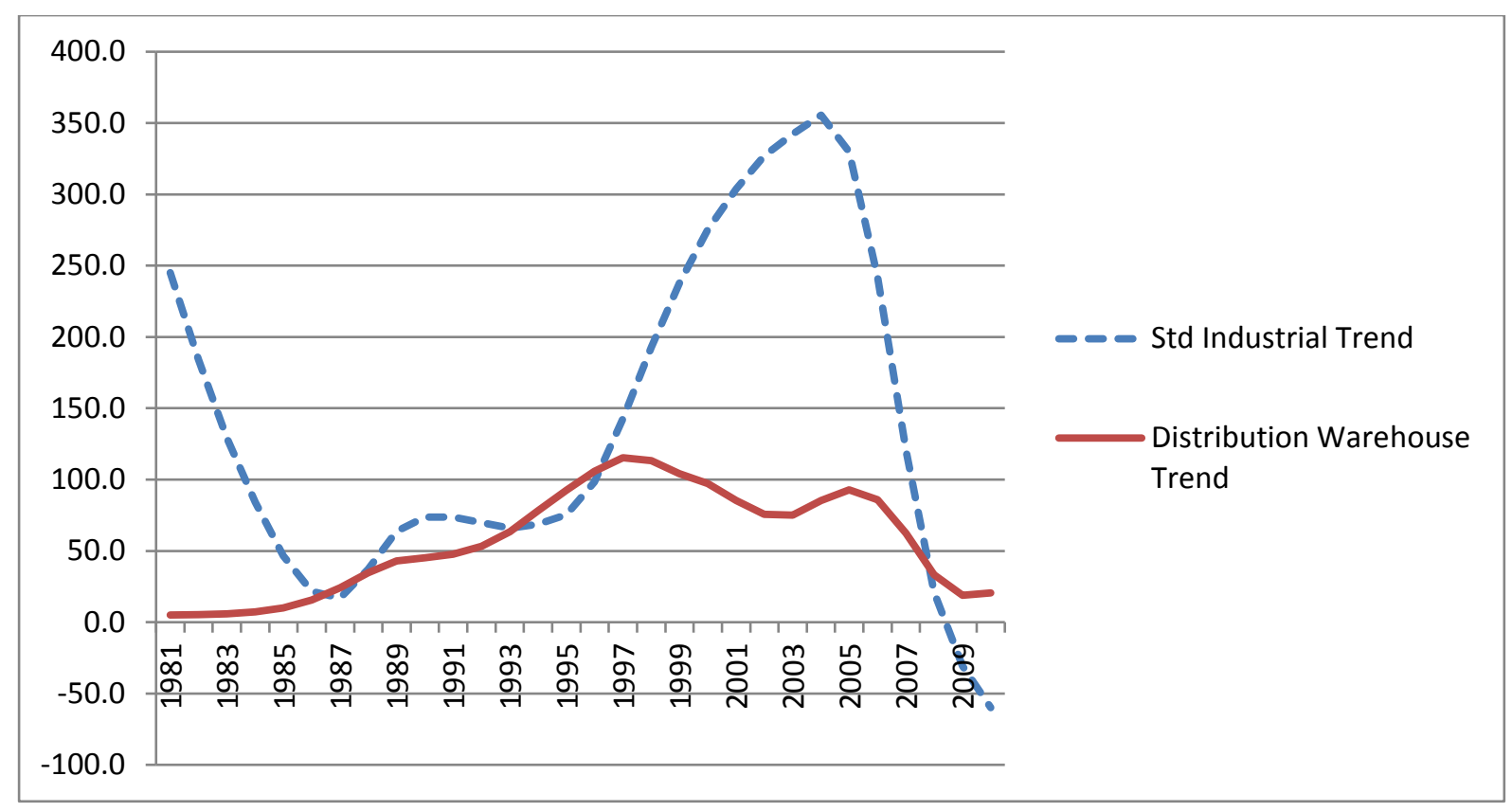

Figure 3 Trends in Net Real Investment in Industrial Units and Distribution Warehouses

Investment trends in standard industrial units, as Figure 3 shows, go through a roller coaster over the thirty year period (even with cycles removed). After a rapid growth in net investment from the mid-1990s culminating in the GFC there is then a period of dis-investment. In contrast net investment in distribution warehousing starts from a low base in the early 1980s and then grows consistently until the late 1990s. Net investment then begins a slow downward trend that accelerates around the GFC.

Overall these patterns reveal that there are distinctive trends in the property investment segments. Nevertheless the statistics have some limitations; they ignore the restructuring of institutional portfolios toward larger properties. While these statistical trends have had cyclical components removed such was the scale and impact of the global financial crisis that it has not been possible to totally remove this effect. Accepting the distortion of the GFC there are clear patterns. In the retail sector there are dramatic increases in investment in shopping centres in the 1980s and retail warehouses in the 1990s. There is similar modest growth in office parks and industrial warehouses. All these peak around the millennium. There is a later dramatic expansion in investment in industrial units. Standard shops suffer a very significant collapse in investment in the 2000s and standard offices after the GFC. While there are specific investment reasons why offices may have been recently sold to foreign investors the explanation for the other trends are less straightforward. It could be the result of sentiment linked to revealed returns, to the changing supply of assets linked to spatial change and both in some way must be linked to optimising a portfolio. The power of these explanations is now assessed in a series of linked sections. 


\section{Changing Investment and Real Estate Investment Returns}

One simple hypothesis is that returns of individual segments have driven the changes of the institutional portfolio, so if returns from say retail warehouses are high then this would induce greater investment in that segment of the property market. The direction of causation is clear in this hypothesis but an alternative reverse causal link can also be posited, that investment in successful (new) real estate segments can bring high returns. While the latter relationship may be complex it does suggest that the interaction between returns and the changing portfolio structure of institutions is muddied. To address this conundrum the analysis applies Granger Causality (GC) tests that focuses on this two way relationship between changing annual returns and netinvestment in each of the ten segments set out in Table 1. Equivalent research of this type (using different property groups) has been based on quarterly or monthly data that is too lumpy with issues about reporting dates. The results were counter intuitive (Fisher et al, 2009; Ling et al, 2009). This study is based on annual returns and net investment for each segment taken from the MSCI/IPD Digest (MSCI/IPD, 2010).

First of all some prerequisites are necessary. The relationships to be considered need to be stationary. For all segments the results for ADF (Augmented Dickey Fuller) unit root tests on the variables are all much larger than the $1 \%$ critical value, so that non-stationary relationships can be strongly rejected. VAR models are then estimated for each segment. A VAR is a statistical model that is used to capture the linear interdependencies between multiple time series. Tests for prediction error indicate that all these structural models have minimum discrepancy and so can be adopted for the Granger analysis. Based on the platform provided by the estimated VAR model GC tests are completed for each segment and the results presented in Table 2.

The test developed by Granger (1969) ascertains the causal relationship between two variables; if past values of $\mathrm{x}$ improve the prediction of $\mathrm{y}$, then we say $\mathrm{x}$ Granger causes y. Conversely, if past values of $y$ contribute to the future value of $x$ than we say y Granger causes x. Column 2 shows the significance of the (statistical) causal relationships from return to net investment and then Column 3 gives it in the reverse direction. The null hypothesis in each case is of no causality. The significance of GC tests is that while ordinarily regressions will reflect a correlation input; GC tests differ in the sense that they reveal causality between variables. 
Table 2 Results of Granger Causality Tests between Annual Return and Net Investment for each Segment

\begin{tabular}{|c|c|c|c|}
\hline $\begin{array}{l}\text { Property } \\
\text { Segment }\end{array}$ & $\begin{array}{c}\text { Annual Return } \\
\rightarrow \text { Net } \\
\text { Investment } \\
\text { Statistical } \\
\text { Significance }\end{array}$ & $\begin{array}{c}\text { Net Investment } \rightarrow \\
\text { Annual Return } \\
\text { Statistical } \\
\text { Significance }\end{array}$ & $\begin{array}{c}\text { Direction of } \\
\text { Causality }\end{array}$ \\
\hline $\begin{array}{l}\text { Standard } \\
\text { Shop }\end{array}$ & 0.585 & 0.002 & $\begin{array}{c}\text { One direction } \\
\text { Investment } \rightarrow \\
\text { Return } \\
\end{array}$ \\
\hline $\begin{array}{l}\text { Shopping } \\
\text { Centres }\end{array}$ & 0.252 & 0.031 & $\begin{array}{c}\text { One direction } \\
\text { Investment } \rightarrow \\
\text { Return }\end{array}$ \\
\hline $\begin{array}{l}\text { Retail } \\
\text { Warehouses } \\
\end{array}$ & 0.038 & 0.131 & $\begin{array}{c}\text { One direction } \\
\text { Return } \rightarrow \\
\text { Investment }\end{array}$ \\
\hline $\begin{array}{l}\text { Department/ } \\
\text { Variety } \\
\text { Stores }\end{array}$ & 0.109 & 0.198 & No direction \\
\hline Supermarkets & 0.003 & 0.186 & $\begin{array}{c}\text { One direction } \\
\text { Return } \rightarrow \\
\text { Investment }\end{array}$ \\
\hline Other Retail & 0.000 & 0.319 & $\begin{array}{c}\text { One direction } \\
\text { Return } \rightarrow \\
\text { Investment }\end{array}$ \\
\hline $\begin{array}{l}\text { Standard } \\
\text { Offices }\end{array}$ & 0.094 & 0.162 & No direction \\
\hline Office Parks & 0.116 & 0.366 & No direction \\
\hline $\begin{array}{l}\text { Standard } \\
\text { Industrials }\end{array}$ & 0.329 & 0.780 & No direction \\
\hline $\begin{array}{l}\text { Distribution } \\
\text { Warehouses }\end{array}$ & 0.025 & 0.059 & $\begin{array}{c}\text { One direction } \\
\text { Return } \rightarrow \\
\text { Investment }\end{array}$ \\
\hline
\end{tabular}

These results show four instances out of the ten segments were changes in return GC causes investment, namely supermarkets, other retail, retail warehouses and distribution warehouses. There are two segments where the opposite holds: for shops and shopping centres net investment GC causes changes in returns. The remaining four segments demonstrate no causality in either direction. It is difficult if not impossible to discern a pattern to the relationships in these results. It could be that a cumulative relationship, namely consistent growth in returns over a period of years, could stimulate net investment, and this is not captured in the Granger causality tests. 
Nevertheless the tests are certainly not a ringing endorsement that changing returns alone drive investment in specific sectors.

Changing Investment and the Balance of Risk and Return in the Institutional Portfolio

The focus in the last section is entirely on returns and ignores the role of risk, and hence the balance between risk and return in portfolio selection. Logically investors respond to adjustments over time to risk and return of individual real estate segments to optimise the institutional portfolio. As noted earlier these decisions are based on expected future returns although in practice such forecasts are partly based on (recent) historic economic and real estate trends and cycles (Baum, 2015; Baum and Hartzell, 2011). This section considers to what extent the institutional portfolio (defined by the proportion of the ten segments) responds over time to reflect the changing balance of risk and return.

Table 3 The Balance of Risk and Return in the 'Institutional Portfolio', 1981-2006

\begin{tabular}{|l|c|c|c|c|c|c|c|c|c|c|}
\hline Start & 1981 & $\mathbf{1 9 8 2}$ & $\mathbf{1 9 8 3}$ & $\mathbf{1 9 8 4}$ & $\mathbf{1 9 8 5}$ & $\mathbf{1 9 8 6}$ & $\mathbf{1 9 8 7}$ & $\mathbf{1 9 8 8}$ & $\mathbf{1 9 8 9}$ & $\mathbf{1 9 9 0}$ \\
\hline End & $\mathbf{1 9 8 5}$ & $\mathbf{1 9 8 6}$ & $\mathbf{1 9 8 7}$ & $\mathbf{1 9 8 8}$ & $\mathbf{1 9 8 9}$ & $\mathbf{1 9 9 0}$ & $\mathbf{1 9 9 1}$ & $\mathbf{1 9 9 2}$ & $\mathbf{1 9 9 3}$ & $\mathbf{1 9 9 4}$ \\
\hline $\begin{array}{l}\text { Annualised } \\
\text { 5 Year } \\
\text { Returns }\end{array}$ & 9.7 & 9.0 & 12.9 & 17.3 & 18.5 & 15.0 & 11.9 & 6.4 & 4.7 & 4.2 \\
\hline $\begin{array}{l}\text { Portfolio } \\
\text { Variance }\end{array}$ & 8.1 & 1.9 & 48.4 & 80.7 & 66.5 & 181.7 & 236.4 & 199.7 & 124.1 & 108.4 \\
\hline $\begin{array}{l}\text { Portfolio } \\
\text { SD }\end{array}$ & 2.9 & 1.4 & 7.0 & 9.0 & 8.2 & 13.48 & 15.4 & 14.1 & 11.1 & 10.4 \\
\hline Start & 1991 & $\mathbf{1 9 9 2}$ & $\mathbf{1 9 9 3}$ & $\mathbf{1 9 9 4}$ & $\mathbf{1 9 9 5}$ & $\mathbf{1 9 9 6}$ & $\mathbf{1 9 9 7}$ & $\mathbf{1 9 9 8}$ & $\mathbf{1 9 9 9}$ & $\mathbf{2 0 0 0}$ \\
\hline End & $\mathbf{1 9 9 5}$ & $\mathbf{1 9 9 6}$ & $\mathbf{1 9 9 7}$ & $\mathbf{1 9 9 8}$ & $\mathbf{1 9 9 9}$ & $\mathbf{2 0 0 0}$ & $\mathbf{2 0 0 1}$ & $\mathbf{2 0 0 2}$ & $\mathbf{2 0 0 3}$ & $\mathbf{2 0 0 4}$ \\
\hline $\begin{array}{l}\text { Annualised } \\
\text { 5 Year } \\
\text { Returns }\end{array}$ & 6.8 & 9.2 & 12.8 & 11.0 & 11.4 & 12.8 & 12.2 & 10.6 & 10.4 & 11.0 \\
\hline $\begin{array}{l}\text { Portfolio } \\
\text { Variance }\end{array}$ & 70.3 & 53.6 & 34.7 & 17.7 & 19.1 & 6.0 & 11.7 & 6.1 & 5.8 & 12.0 \\
\hline $\begin{array}{l}\text { Portfolio } \\
\text { SD }\end{array}$ & 8.4 & 7.3 & 5.9 & 4.2 & 4.4 & 2.5 & 3.4 & 2.5 & 2.4 & 3.5 \\
\hline Start & $\mathbf{2 0 0 1}$ & $\mathbf{2 0 0 2}$ & $\mathbf{2 0 0 3}$ & $\mathbf{2 0 0 4}$ & $\mathbf{2 0 0 5}$ & $\mathbf{2 0 0 6}$ & $\mathbf{2 0 0 7}$ & & & \\
\hline End & $\mathbf{2 0 0 5}$ & $\mathbf{2 0 0 6}$ & $\mathbf{2 0 0 7}$ & $\mathbf{2 0 0 8}$ & $\mathbf{2 0 0 9}$ & $\mathbf{2 0 1 0}$ & $\mathbf{2 0 1 1}$ & & & \\
\hline $\begin{array}{l}\text { Annualised } \\
\text { 5 Year } \\
\text { Returns }\end{array}$ & 12.7 & 15.0 & 12.3 & 5.8 & 3.0 & 2.2 & 0.1 & & & \\
\hline $\begin{array}{l}\text { Portfolio } \\
\text { Variance }\end{array}$ & 22.2 & 15.9 & 73.3 & 269.1 & 235.4 & 212.2 & 161.9 & & & \\
\hline
\end{tabular}




\begin{tabular}{|l|l|l|l|l|l|l|l|l|l|l|}
\hline $\begin{array}{l}\text { Portfolio } \\
\text { SD }\end{array}$ & 12.7 & 15.0 & 12.3 & 5.8 & 3.0 & 2.2 & 0.1 & & & \\
\hline
\end{tabular}

The empirical analysis is based on the annual aggregate institutional portfolios as given by the MSCI/IPD database. We construct the changing profile of the risk and return of the aggregate institutional portfolio year by year from 1981 to 2007. Each year in Table 3 represents the expected 5 year return and risk of the 'institutional portfolio' in that year defined by the proportions of the ten property segments in Table 1. It draws on the arguments earlier by taking a five year forward timeline, and investors are effectively presumed to have perfect foresight so that the actual figures from MSCI/IPD can be used to calculate anticipated returns and risk (standard deviation). Obviously in reality investors do not have perfect future knowledge but rely on forecasts based primarily on past data. These forecasts aim to predict the future so another way of looking at this assumption is that the forecasts are (almost) accurate.

Despite the emphasis of investment theory it is exceedingly difficult to see an optimising pattern to these statistics. Only in the 1990 s in what was a relatively stable period is there a trend of falling risk with generally stable returns. In fact examination of the raw statistics (not presented) suggests that an optimum strategy would be to switch into a growth segment, say retail warehouses, for five years and then move investment into another with better growth prospects. This is clearly unrealistic as portfolios in practice reflect their historic construction and can only adapt relatively slowly to market conditions, including the supply of assets available. Arguably the structure of investment portfolios is the result of a complex nexus of factors with investors fumbling around trying to implement strategies driven by forecasts of prospective returns as best they can.

It is possible that the other measures of risk noted above would have produced different results. Measures that focused on downside risk would have produced even higher scores during the downturns, but they are unlikely to address the lack of consistent temporal pattern. Even with the use of the standard deviation as the measure of risk the pattern is dominated by the impact of real estate cycles as Figure 4 shows, especially the global financial crisis. This reflects the fact that real estate investment decisions/forecasts and portfolio analysis have difficulty predicting and coping with turning points. 


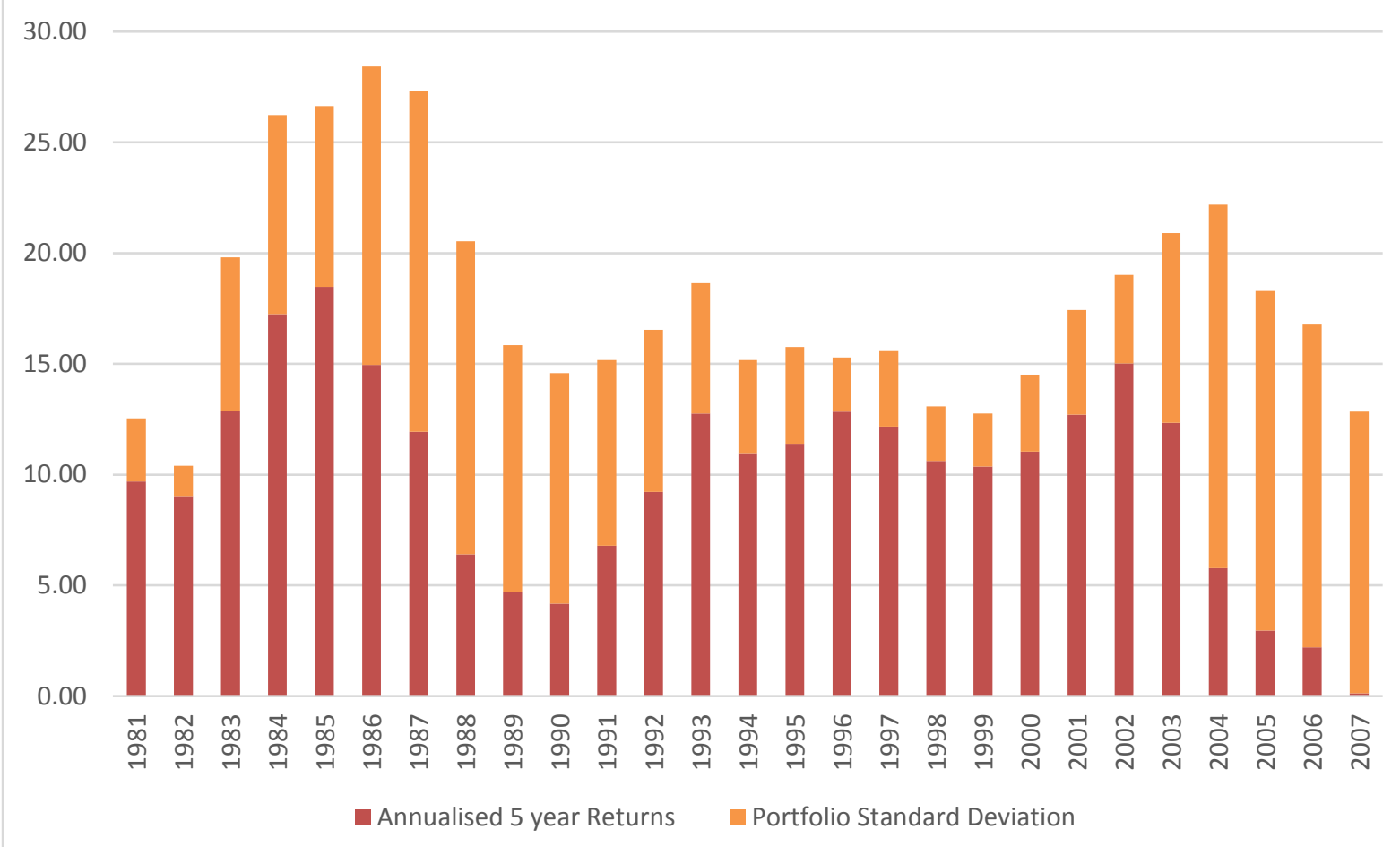

Figure 4 Annualised 5 year Returns and Risks of Portfolios 1981-2007

\section{Investment and the Changing Supply of Assets}

The final issue to consider is role of supply constraints in the choice of assets. By definition the stock of real estate at any point in time is fixed, and so acts a constraint on investment strategies. This is different from the constrained optimisation of say the Black-Litterman model, caused by for example risk targets (Litterman, 2003). Furthermore financial institutions, REITs and other large investors own much of the 'top quality' of real estate stock of cities. A study by Key and Law (2005) of the UK estimated that these investments account for $61 \%$ and $63 \%$ of the capital value of the national retail and office stock respectively in 2003 (see Table 4). The remaining stock in these sectors is primarily owner occupied or secondary/tertiary stock. As the rental and capital values of the investment stock tend to be higher in terms of space the non-investment sector is about $70 \%$ of the overall total.

By 2013 Mitchell (2014) estimates that the investment sector is 56\% of the total property stock, and that the MSCI/IPD's UK database covers around two-fifths of this investment universe. MSCI/IPD contributors are more biased toward retail than other investors, owning more than half of the retail investment stock. The biggest of the other investors are unlisted property companies or 
overseas investors, the latter of whom who strongly favour offices. The structure of the ownership of the investment stock broken down by segments is shown in Table 5. It demonstrates the dominant impact on (central) London offices of overseas investors. In parallel three quarters of 'investment quality' retail warehouses and three fifths of shopping centres by value are owned by financial institutions. Similarly seven out of ten industrial investment properties are owned by financial institutions. This inevitably means substantial restraints on investment.

Table 4 The 'Invested' and Total Stock by Sector and Value at the end of 2003

\begin{tabular}{|c|c|c|c|c|}
\hline & Retail & Office & Industrial & Total \\
\hline $\begin{array}{l}\text { MSCI/IPD } \\
\text { Contributors }\end{array}$ & 65 & 41 & 18 & 124 \\
\hline $\begin{array}{l}\text { Investors } \\
\text { (outside IPD) }\end{array}$ & 59 & 59 & 12 & 129 \\
\hline Total & $f^{202 b n}$ & £159bn & f127bn & $£ 489 \mathrm{bn}$ \\
\hline $\begin{array}{l}\text { Investment } \\
\text { Stock as \% of } \\
\text { Total }\end{array}$ & $61 \%$ & $63 \%$ & $23 \%$ & $52 \%$ \\
\hline
\end{tabular}

Source: Table 7, Key and Law (2005)

Table 5 Breakdown of Investment Stock by Financial Institutions and Overseas Investors (fbn)

\begin{tabular}{|l|c|c|c|}
\hline Property Segment & $\begin{array}{c}\text { Financial } \\
\text { Institutions* }\end{array}$ & Overseas & Total \\
\hline $\begin{array}{l}\text { Central London Shops } \\
\text { (included in standard SE } \\
\text { Retail) }\end{array}$ & 6 & 2 & 15 \\
\hline $\begin{array}{l}\text { Standard Retail South } \\
\text { East }\end{array}$ & 14 & 3 & 29 \\
\hline Standard Retail (RUK) & 14 & 7 & 24 \\
\hline Shopping Centres & 32 & 3 & 43 \\
\hline Retail Warehouses & 32 & 24 & 38 \\
\hline Offices in City & 22 & 13 & 53 \\
\hline $\begin{array}{l}\text { Offices in West End } \\
\text { and Mid-Town }\end{array}$ & & & \\
\hline
\end{tabular}




\begin{tabular}{|l|c|c|c|}
\hline $\begin{array}{l}\text { Offices in Rest of } \\
\text { London (included in } \\
\text { rest of SE) }\end{array}$ & 5 & 11 & 23 \\
\hline $\begin{array}{l}\text { Offices in Rest of South } \\
\text { East }\end{array}$ & 14 & 14 & 39 \\
\hline Offices in Rest of UK & 7 & 4 & 16 \\
\hline $\begin{array}{l}\text { Industrials in South } \\
\text { East }\end{array}$ & 16 & 1 & 22 \\
\hline $\begin{array}{l}\text { Industrials in Rest of } \\
\text { UK }\end{array}$ & 12 & 11 & 32 \\
\hline Other Commercial & 182 & 88 & 384 \\
\hline Total & & & 18 \\
\hline
\end{tabular}

*includes insurance companies, pension funds, collective investment schemes and listed property.

The balance is made up of private property companies, traditional estates and charities, private and other investors.

\section{Source: Derived from Table D.7 (Mitchell, 2014) P61}

These figures do not take into account that only a subset of the stock is attractive or appropriate for investment by financial institutions. Mitchell (2014) notes that by 2013 retail and industrial assets valued less than $£ 1.5 \mathrm{~m}$ and offices of less than $£ 2.5 \mathrm{~m}$ rarely feature in most institutional investors' portfolios. The industrial sector in particular has a small percentage of stock that is attractive to financial institutions and other investors. The result is that almost half the value of the UK's property stock by value, many owned by their occupiers, does not meet the current investment requirements of large investors. In other words large investors effectively and collectively own all the stock and more that is currently deemed appropriate to their needs.

These investment needs have changed over time. A large proportion of high street shops are now too small to meet investors' criteria and there was a substantial disinvestment from the mid-1990s as shown earlier (Jones, 2010). This trend was counter-balanced by a growth of investment in shopping centres and retail warehouses characterised by the large lot sizes that are also seen as more appropriate to meet the evolving needs of retailers and shoppers (Mitchell, 2014).

The investment trends not only reflect changing investment criteria by financial institutions but also supply. A complete quantitative assessment of the real estate stock over time on an annual 
basis is not available. Undoubtedly property booms expand supply but the net calculation is difficult. For example it is estimated that new office development during the 1980s made a net addition of nearly 30 per cent to the stock of central London, including a new docklands office area centring on Canary Wharf, over the decade (Feinstein, 1994). Within the submarket of the City of London the increase in stock was the order of 10 per cent, with much of these new offices involving redevelopment of existing offices (Jones, 2013).

The institutional property investment stock has not just expanded but been restructured by the urban development cycle noted above. Property investment has had to adapt to new demand requirements and new supply through new building, refurbishment and building obsolescence/ potential redevelopment. In this process of change financial institutions were certainly at first very conservative. Jones (2009) reports on the processes by which retail warehouses and office parks were eventually accepted in institutional portfolios. As new property forms they were initially developed by property companies who were more prepared to innovate and take risks. Gradually the risk premiums attributed to these property forms were eroded and yields fell as investment markets for these property types were established, and probably the diversification benefits recognised.

The ultimate result of these developments is that the institutional portfolio in 2010 as noted earlier is very different from that in 1981. The net impact is clearer for 'new' segments and illustrated here by retail warehouses and in/out of town shopping centres. Retail warehouses were an invention of the 1980s and new development of this property form continued through the 1990s and 2000s as Figure 5 indicates. Figure 6 also demonstrates the rise of the out of town shopping centre, with an increase in such floorspace every year from 1976 to 2014. The expansion of in town shopping centres too demonstrates the restructuring of town centres away from high street shops. In these cases there has been a substantial long term rise in the supply of these assets that aligns with the rise of these assets within the institutional portfolio set out in Table 1. 


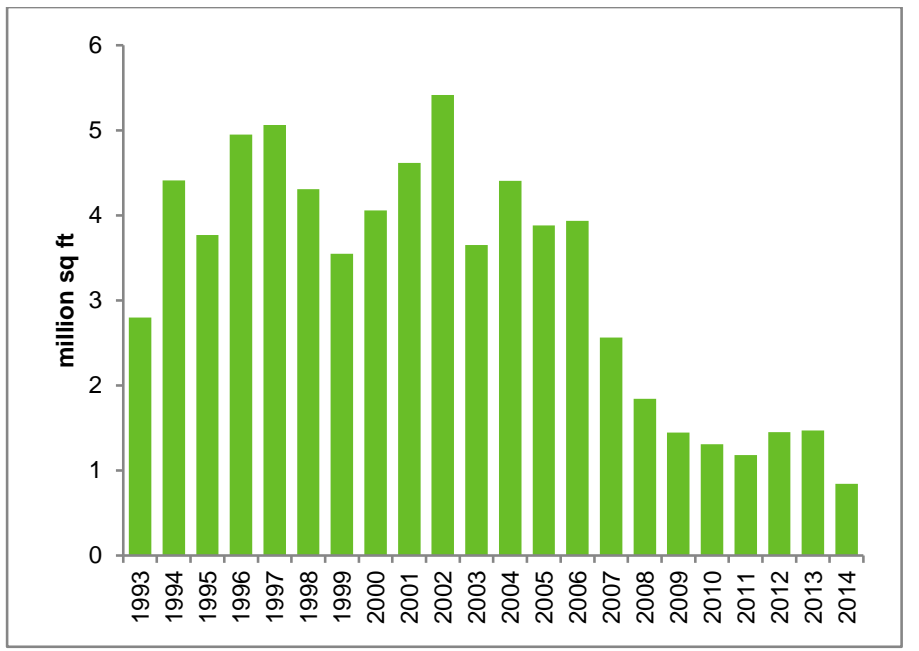

Figure 5 Annual Retail Warehouse Space completed 1993-2014

Source: CBRE (201a)

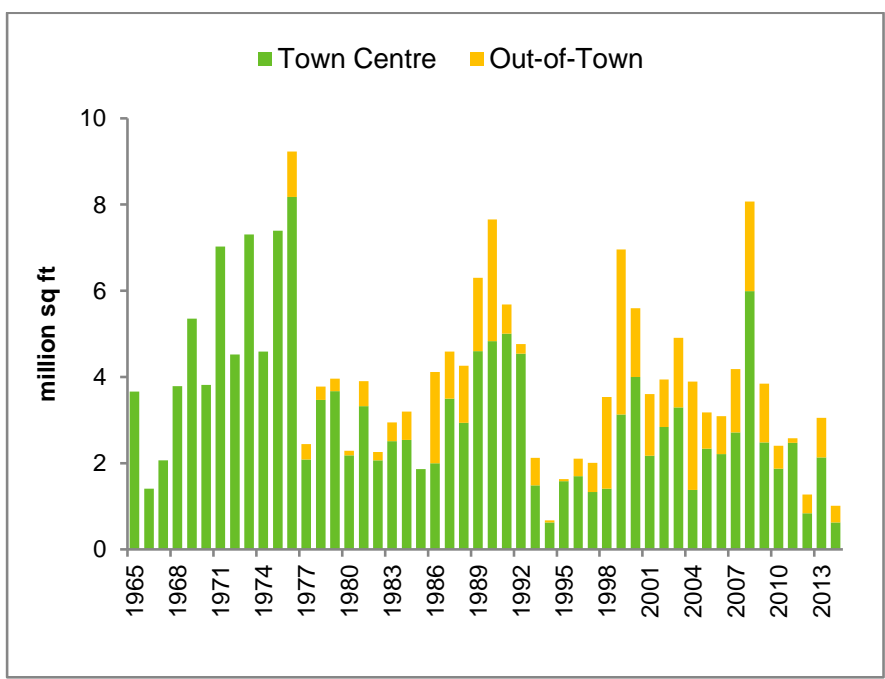

Figure 6 Annual Completions of Town Centre and Out-of-Town Shopping Centres 19652014

Source: CBRE (2014b)

It should be recognised that this process of net change incorporates both buying and selling. In the buy/sell process on the one hand financial institutions can only buy what is available and this is the crucial constraint emphasised in this paper. The sales by financial institutions one could argue are by choice. As noted earlier many London offices have been sold to overseas investors who were prepared to pay much higher prices than the domestic valuations placed on them. . This is evidently a choice that is influenced by the prices on offer. But this phenomenon is exceptional in terms of the adjustment processes through the three decades of this study It is an exogenous shock. A better example was the disinvestment in standard shops, also noted earlier. In just over 
ten years financial institutions sold off more than half the shops they had owned in 1994 (Jones, 2010). In one sense it was a 'choice' but it can more realistically be viewed as a necessity as many of these shops were obsolescent, too small and in the wrong place as the nature of retailing and cities evolved. As a result yields on shops rose relative to other retail forms. The dominant influence was constraint as financial institutions adjusted to a new urban world.

\section{Conclusions}

There have been substantial changes to the institutional real estate portfolio over 30 years as defined by the MSCI/IPD universe. Simply disaggregating real estate investment into three basic classes - offices, retail and industrial - masks this transformation that has occurred. The corollary is that the analyses of risk and return of portfolios based on these sectors give a very misleading picture. The research here has divided UK real estate into ten segments encompassing different forms of retail from out of town shopping centres to standard high street shops, standard offices and office parks, and industrial units and distribution warehousing. The paper shows, using the HP filter that there are clear long term trends in the net real investment of the ten segments over the thirty years 1981-2010.

There are a number of potential reasons for the restructuring of the 'institutional portfolio'. The study examines whether it can be simply explained by returns driving investment patterns, portfolio optimisation or the transformation of the urban system changing the supply of investable assets. The logic of the paper has been to examine the power of these explanations, rather than provide formal tests.

The role of returns is considered via GC analysis. The results are far from conclusive that net investment follows short-term returns. This is a minority position and in fact in some instances the reverse is true, returns follow investment. For four segments there is no causality in either direction. Overall the explanation that changing short-term returns, certainly in isolation, drive investment is not tenable. The optimisation of the institutional portfolio based on a five year time frame is even less convincing as an explanation of the investment trends as the risk and return figures are dominated by the macroeconomy and real estate cycles. These results expose the limitations of portfolio theory in terms of information and predicting the future, and the fact that to achieve an optimum balance of risk and return there would need to be active switching between segments. However, the HP trends demonstrate this does not occur. The reality is that institutional portfolios change slowly like a battleship turning dependent on the supply of assets 
available. The research also generally offers challenges to retrospective academic portfolio studies based on three land use sectors.

Examination of the role of the supply of assets is considered in a number of indirect ways. There is a clear association between the changing institutional portfolio and the supply of new types of assets such as retail warehouses. The HP net investment and development trends are closely linked and while the latter are driven by urban change there must be also a long term financial incentive for this occurrence. The GC analysis shows that there is partial evidence to support this perspective. Institutional portfolios are reconfigured slowly each year shaped by the supply of assets available. This active institutional portfolio restructuring can be most convincingly linked to the new (and larger) properties in the particular segments that have emerged in the latest urban development cycle. The reason lies in the fact that evolving occupier demand (and hence supply) with long term urban economic change must be the bedrock of investment decisions.

The paper does not demonstrate the absolute primacy of the role of supply as a determinant of the restructuring of the institutional property portfolio but identifies it as a significant factor that has been overlooked to date. The paper has considered this through the prism of the property investment implications of urban change but the arguments could apply to the supply of UK assets in infrastructure and the residential sector. 


\section{References}

Backus D K and Kehoe P J (1992) International evidence on the historical properties of business cycles, American Economic Review, 82, 4, 864-888.

Barras R (1987) Technical change and the urban development cycle, Urban Studies, 24, 1, 5-30.

Baum A (2015) Real Estate investment: A Strategic Approach, Taylor and Francis, Abingdon.

Baum A and Hartzell (2011) Global Property Investment: Strategies, Structures, Decisions , Wiley-Blackwell, Chichester.

Baxter M and King R G (1999) Measuring business cycles: Approximate band-pass filters for economic time series, Review of Economics and Statistics, 81, 4, 575-593.

Byrne P J and Lee S L (2004) Different risk measures: Different portfolio compositions? Journal of Property Investment and Finance, 22, 6, 501-511.

Byrne P and Lee S L (2011) Sector, region or function? A MAD reassessment of real estate diversification in Great Britain. Journal of Property Investment and Finance, 29, 2, 167-189.

Campbell J Y and Viceira L M (2005) Term structure of the risk-return trade-off, Financial Analysts Journal, 61, 1, 34-44.

CBRE (2014a) UK Retail Warehouse Parks in the Pipeline: Market View, CBRE, London. CBRE (2014b) UK Shopping Centres in the Pipeline: Market View, CBRE, London. Cooley T J and Ohanian L E (1991) The cyclical behavior of prices, Journal of Monetary Economics, 28, 1, 25-60.

Correia I H, Neves J L and Rebelo S T (1992) Business cycles from 1850-1950: New facts about old data, European Economic Review, 36, 2/3, 459-467.

Dunse N, Jones C and White M (2010) Valuation accuracy and spatial variations in the efficiency of the property market, Journal of European Real Estate Research, 3, 1, 24-45.

Fainstein S (1994) The City Builder: Property, Politics and Planning in London and New York, Blackwell, Oxford.

Fisher J, Ling D C and Naranjo A(2009) Institutional Capital Flows and Return Dynamics in Private Commercial Real Estate Markets, Real Estate Economics, 37, 1, 85-116. 
Geltner D (2000) Benchmarking manager performance within the private real estate investment industry, Real Estate Finance, Spring, 23-34.

Granger C W J (1969) Investigating causal relationship by econometric models and cross spectral methods, Econometrica, 37, 3, 424-438.

Hamelink, F. and Hoesli, M. (1996) Conditional heteroscedasticity and real estate in diversified portfolios: an application of the QTARCH methodology, Journal of

Property Research, 13, 1, 17-30

Henneberry J and Roberts C (2008). Calculated inequality? Portfolio benchmarking and regional office property investment in the UK. Urban Studies, 45, 1217-1241.

Hodrick R and Prescott E C (1997) Postwar US business cycles: An empirical investigation, Journal of Money, Credit, and Banking, 29, 1, 1-16.

Hoesli M and MacGregor B (2000) Property Investment. Longman, Harlow.

Hoesli M and Oikarinen (2012) Are REITs real estate? Evidence from international sector level data, Journal of International Money and Finance, 31, 7, 1823-1850.

Jackson C (2013) Diversification of portfolio risk: Reconciling theory and observed weightings, Journal of Property Research, 30, 4, 266-297.

Jones C (2009) Remaking the monopoly board: Spatial economic change and property investment, Urban Studies, 46, 11, 2363-2380.

Jones C (2010) The rise and fall of the high street shop as an investment class, Journal of Property Investment Finance, 28, 4, 275-284.

Jones C (2013) Office Markets and Public Policy, Wiley-Blackwell, Chichester.

Jones C, Cowe S and Trevillion E (2017) Property Boom, Banking Bust, Wiley-Blackwell, Chichester.

Jones C, Livingstone N and Dunse N (2016) "The Changing Nature of Transactions Activity and Liquidity in UK Commercial Property: Cyclical and Trend Effects" International Journal of Strategic Property Management, 20, 4, 384-396.

Kaiser R W (2005) Analyzing real estate portfolio returns, Journal of Portfolio Management, Special Issue, September, 134-42. 
Kaiser R W and Clayton J (2008) Assessing and managing risk in institutional real estate investing, Journal of Real Estate Portfolio Management, 14, 4, 287-306.

Key T and Law V (2005) The Size and Structure of the UK Property Market, Investment Property Forum, London.

Kroencke T A, Schindler F and Steininger B I (2014) Are REITs Real Estate or Equities? Dissecting REITs in an Asset Pricing Model, European Public Research Association, Brussels.

Liang Y and McIntosh W (1998) REIT Style and Performance, Journal of Real Estate Portfolio Management, 4, 1, 69-78.

Litterman (2003) Modern Investment Management: An equilibrium Approach, Wiley, New Jersey.

Ling D C, Marcato G and McAllister P (2009) Dynamics of asset prices and transaction activity in illiquid markets: The case of private commercial real estate, Journal of Real Estate Finance and Economics, 39, 359-383.

Lizieri C (2009). Towers of Capital: Office Markets and International Financial Services.

Wiley-Blackwell, Chichester

MacGregor B D and Nanthakumaran N (1992) The allocation to property in the multi-asset portfolio: the evidence and theory reconsidered, Journal of Property Research, 9, 1, 5-32.

Markowitz H (1952) Portfolio selection, Journal of Finance, 7, 1, 77-91.

Mitchell P (2014) The Size and Structure of the UK Property Market 2013: A Decade of Change, Investment Property Forum, London.

MSCI/IPD, Investment Property Databank (2010) IPD Digest, IPD, London.

Ravn M O and Uhlig H (2002) "On adjusting the Hodrick-Prescott Filter for the frequency of observations, Review of Economics and Statistics, 84, 2, 371-380.

Rehring C (2012) Real estate in a mixed-asset portfolio: The role of the investment horizon, Real Estate Economics, 40, 1, 65-95.

Scott P (1996) The Property Masters, E\&FN Spon, London. 
Sivitanides P S (1996) Property-Type Diversification in Real Estate Portfolios: Multi-Period Return Measures vs. Single-Period Return Measures, Journal of Real Estate Portfolio Management, 2, 2, 127-40. 